Article

\title{
Bioleaching of Major, Rare Earth, and Radioactive Elements from Red Mud by using Indigenous Chemoheterotrophic Bacterium Acetobacter sp.
}

\author{
Yang $\mathrm{Qu}{ }^{1}{ }^{1} \mathbb{0}$, Hui $\mathrm{Li}^{1}{ }^{1}$, Xiaoqing Wang ${ }^{1}$, Wenjie Tian ${ }^{1}$, Ben Shi ${ }^{1}$, Minjie Yao ${ }^{2}$ and Ying Zhang ${ }^{3}$ \\ 1 Department of Environmental Engineering and Chemistry, Luoyang Institute of Science and Technology, \\ Luoyang 471023, China; orient.lihui@hotmail.com (H.L.); xiaoqingwang@lit.edu.cn (X.W.); \\ twj7210@lit.edu.cn (W.T.); POP100@163.com (B.S.) \\ 2 Key Laboratory of Environmental and Applied Microbiology, Environmental Microbiology Key Laboratory \\ of Sichuan Province, Chengdu Institute of Biology, University of Chinese Academy of Sciences, \\ Sichuan 610041, China; yaomj@cib.ac.cn \\ 3 School of Resources and Environment Engineering, Guizhou Institute of Technology, Guiyang 550003, China; \\ zhangying2701@sina.com \\ * Correspondence: quyang85@hotmail.com
}

Received: 12 December 2018; Accepted: 13 January 2019; Published: 22 January 2019

\begin{abstract}
The aim was to study the bioleaching performance of chemoheterotrophic bacterium involved in leaching of major, rare earth, and radioactive elements from red mud (RM), and to explore the underlying mechanism. An acid-producing bacterium, identified as Acetobacter sp., was isolated from RM impoundment and used in the bioleaching experiments under one-step, two-step and spent medium process at up to $10 \%$ pulp density. The results showed that the leaching ratios of $\mathrm{Al}, \mathrm{Lu}, \mathrm{Y}$, Sc, and Th were $55 \%, 53 \%, 61 \%, 52 \%$, and $53 \%$ respectively under one-step process at $2 \%$ pulp density. Under both one- and two-step processes at $2 \%$ pulp density, the radioactivity of bioleached RM can meet the relevant regulation in China. The total amount of organic acids excreted by Acetobacter sp. increased with an increase of RM pulp density. After bioleaching, contents of hematite and gibbsite decreased but perovskite increased in RM. Micromorphology analysis indicated that the cells of Acetobacter sp. adhered to RM particles and formed large-size aggregates, and a new crystal of weddellite emerged. In view of the shorter lag phase and smaller biomass comparing to fungi even under direct contact with RM, bacterium Acetobacter sp. is supposed to apply to in situ heap or dump bioleaching of RM.
\end{abstract}

Keywords: chemoheterotrophic bacterium; Acetobacter; red mud; bioleaching; radioactive elements

\section{Introduction}

Aluminum, as one of the most important light metal, is commonly existed in oxide form known as bauxite. The bauxite residue named as red mud (RM), is a highly alkaline waste byproduct generated from Bayer or sintering process for producing alumina. On a global scale, more than 3.5 billion tons of RM stockpiled in RM storage area, with an increasing rate of 120 million tons per year [1,2]. Being highly alkaline and difficult to deal with, RM presents a significant environmental hazard, especially when spilled out of the clay-lined impounds designed to contain it. The disposal of RM remains an environmental concern all around in the alumina-aluminum producing countries.

Therefore, it is urgent to develop a safe and efficient technology to recycle RM. Utilizing RM as the raw construction materials is a promising way to decrease the huge storage volume of RM. However, the RM is frequently not up to the relevant standard for construction materials' radioactivity, and thus the amount of RM added into concrete or cement is strictly restricted [3] 
RM is defined as a kind of "polymetallic raw material" or "artificial ore" for the high content of valuable metals, e.g., aluminum, iron, titanium, rare earth elements, radioactive elements, etc. [4]. The first step to recover valuable metals in RM is leaching them into solution. Employing chemical leaching agents such as sulfuric, nitric and hydrochloric acids to extract metals from RM has been widely studied $[4,5]$. Comparing to conventional chemical leaching, bioleaching process is generally considered as a "green technology" with low energy requirement, operational flexibility and mildness, relative simplicity and environmental benignity, and has become an increasingly focus of researchers recently $[6,7]$.

The microorganisms play a key role in bioleaching process. There are two different types of microorganisms involved in bioleaching: chemoautotroph and chemoheterotroph. Chemoautotroph are not suitable for leaching RM since they are not active in alkaline environment [8]. Besides, an energy resource such as sulfur or reduced iron to support the growth of chemoautotrophic bacteria is unavailable in RM. In comparison, chemoheterotroph can grow better in the presence of RM due to their fast growth, quick adaptation to alkalinity and acidity, and high tolerance to metal ions [9]. Although the cost of adding carbon and energy sources is indispensable to chemoheterotroph, it can be decrease by providing organic wastes [8].

Fungi and bacteria are the two groups of chemoheterotroph used as bioleaching strains. Fungal strains such as Aspergillus and Penicillium, have been reported to be applied into RM bioleaching [3,9-12]. However, the disadvantages of bioleaching with fungal strains appeared in our pilot-scale test.

First, huge amounts of biomass were generated through the assimilation activity of fungi, resulting in a high cost to deal with the waste biomass. Second, it was difficult to separate the RM particles from fungal biomass after bioleaching, which led to two problems: a loss of RM particles and a difficulty to deal with the hyphae-RM mixture. Third, spores generated from the fungi in bioleaching process were easily to cause environmental pollution.

Comparing to fungi, chemoheterotrophic bacteria is probably more suitable for RM bioleaching since they can avoid the disadvantages mentioned above. However, research about bioleaching of RM with chemoheterotrophic bacteria is seldom until now. This limits our understanding on actual potentiality of the bacteria for leaching RM in a laboratory as well as industrial scale. Therefore, the main objectives of this study are to explore the metal leaching performance of RM and the underlying mechanism by using chemoheterotrophic bacteria as the leaching strain.

\section{Materials and Methods}

\subsection{Red Mud}

Two different kinds of RM samples were collected from the RM storage area $\left(26^{\circ} 41^{\prime} \mathrm{N}, 106^{\circ} 35^{\prime} \mathrm{E}\right)$ of Chinalco in southwest of China. One RM, stored for over 20 years in the bottom of the layered impoundment, was used for bacteria isolation. The RM samples were collected in sterile laminated stainless steel containers and then stored at $4{ }^{\circ} \mathrm{C}$ in refrigerator waiting for isolating microbes. The other RM, collected from the outlet of discharge pipe, was used for bioleaching test. Dried the second RM samples in an oven at $80^{\circ} \mathrm{C}$ for $72 \mathrm{~h}$, and powdered to 200 mesh. Contents of metal element and mineral composition of the RM were determined before bioleaching experiments.

\subsection{Screening and Identification of Leaching Bacterial Strain}

The first kind of RM sample was directly plated on nutrient agar media, tryptic soya media and Horikoshi media supplement with $\%(v / w)$ RM by serial dilution method [13]. The target colonies were isolated and purified after the RM samples incubated at $30^{\circ} \mathrm{C}$ for $36 \mathrm{~h}$. A total of 22 pure bacterial strains were isolated. Each of strains was cultured in test medium and the $\mathrm{pH}$ value was monitored for 10 days. The composition of test medium (g/L): beef extract 10; peptone 20; yeast extract 20, and RM 50 . 
Eventually, a strain named RM-B07 with lowest $\mathrm{pH}$ value of the medium during cultivation period among all the strains was chosen as bioleaching strain.

In order to identify the bioleaching strain, physiological and biochemical tests were performed based on "Bergey's Manual of Determination Bacteriology" [14]. Moreover, the gene sequence of $16 \mathrm{~S}$ rRNA was analyzed and compared with registered sequence by Basic Local Alignment Search Tool (BLAST) in NCBI GeneBank database. A phylogenetic tree was constructed by the neighbor-joining method. The experimental details of gene analysis were described in our previous study [15].

\subsection{Bioleaching Experiments}

Strain RM-B07 was inoculated into leaching medium and incubated at $30{ }^{\circ} \mathrm{C}$ and $120 \mathrm{rpm}$ in an orbital shaking incubator for $24 \mathrm{~h}$ for activation. Then $2 \mathrm{~mL}$ of bacterium suspension was inoculated into $100 \mathrm{~mL}$ of leaching medium in a $250 \mathrm{~mL}$ Erlenmeyer flask with different pulp densities $(2,5$, and $10 \%$ ) of sterilized RM. It was incubated at $30^{\circ} \mathrm{C}$ and $120 \mathrm{rpm}$ until the $\mathrm{pH}$ value of leaching solution kept invariable. The composition of leaching medium (g/L): absolute ethyl alcohol 30, glucose 10, and yeast extract 10 .

Three different kinds of bioleaching processes were used: (i) the bacterium was inoculated into leaching medium together with RM (one-step process); (ii) pre-cultivated of the bacterium in leaching medium for 2 days before RM added into (two-step process); (iii) RM was added into cell-free spent medium which was obtained by filtering bacterium suspension through a filter membrane $(0.2 \mu \mathrm{m}$, Whatman) after 6 days incubation of strain (spent medium process).

In each treatment, $2 \mathrm{~mL}$ samples were withdrawn at regular intervals for analyzing bacterial cell numbers, $\mathrm{pH}$ value, metal ions, and organic acids concentration. Control experiments were performed by using deionized distilled water and fresh leaching medium. All the culture mediums involved in this study were sterilized by autoclaving at $121^{\circ} \mathrm{C}$ for $15 \mathrm{~min}$ before use. All experiments were run in triplicate.

\subsection{Analytical Methods}

The numbers of bacterial cell during bioleaching process was counted performed by standard plate count (SPC) method, which had a primary advantage that only living cells of bacteria was quantifying [16]. In this method, the results will be influenced easily by RM particles since the RM particles adhered by microbial cells can go onto the surface of solid media. For trying to avoid the disturbance of RM particles, the Erlenmeyer flask was stationary for 10 min to make the particles settle to the bottom before collected the samples of the supernatant.

The mineral composition of RM was determined by using X-ray diffraction (XRD; Axios PW4400, PANalytical B.V., Luoyang, China) with diffraction angle was performed from $5^{\circ}$ to $60^{\circ}$. Peak identification was performed using software Jade 6.5 (MDI, Ivermore, CA, USA).

The determination methods of $\mathrm{pH}$ value, acid neutralization capacity (ANC), electrical conductivity (EC), metal ions concentration, organic acids concentration, elements composition, radionuclides concentration, and micromorphology of bacteria and RM were described in detail in our previous studies [3,12].

\section{Results and Discussion}

\subsection{Screening and Identification of Strain RM-B07}

The $\mathrm{pH}, \mathrm{EC}$, and ANC of the second kind of samples collected from the outlet of discharge pipe were $12.9,21.8 \mathrm{mS} / \mathrm{cm}$, and $3.53 \mathrm{mmol} \mathrm{H}^{+} / \mathrm{g}$ respectively. No bacterial strain was isolated from these samples. This result verified that the number of living cells of chemoheterotrophic microbes in fresh RM was close to zero due to extremely low level of nutrients as well as high toxicity $[13,17]$.

The $\mathrm{pH}, \mathrm{EC}$, and ANC of the first kind of samples, which located in the bottom of the layered $\mathrm{RM}$ impoundment for over 20 years, were $9.8,9.2 \mathrm{mS} / \mathrm{cm}$, and $3.06 \mathrm{mmol} \mathrm{H} \mathrm{H}^{+} / \mathrm{g}$ respectively. 
Approximately $5 \mathrm{~mm}$ depth of algae crust with green color grew on the surface of the sampling point, which indicated a spontaneous primary succession occurred and the microbial diversity developed. Twenty-two different chemoheterotrophic bacterial strains were isolated from these RM samples. Because acidolysis is one of the most important mechanism in heterotrophic bioleaching [11], the strain named RM-B07, having the maximum acids production during the cultivation in the presence of RM, was chosen as the bioleaching functional strain.

The colony morphology of strain RM-B07 were yellowish-brown, semitransparent, slabby, and circular with smooth edge. The physiological test results of strain RM-B07 were shown in Table 1. Because one genus usually shows morphologic variation in different living conditions and growing stages [18], the homology analysis of 16S rRNA of strain RM-B07 was deployed. The nucleotide sequencing data were submitted to the GenBank nucleotide sequence database and the accession number was JF909351. Figure 1 showed the phylogenetic relationships of the 16S rRNA gene sequences of strain RM-B07 with related sequences in GenBank database. These results revealed that strain RM-B07 was belong to Acetobacter sp.

Table 1. Physiological characteristics of strain RM-B07.

\begin{tabular}{cccc}
\hline & Biochemical Test & \\
\hline Anaerobic growth & - & Catalase & + \\
Mobility & - & Oxidase & - \\
Gram staining & - & $\mathrm{H}_{2} S$ production & - \\
Glucose glycolysis & + & MR test & + \\
Sucrose glycolysis & + & VP test & - \\
Lactose glycolysis & + & Indole & - \\
Amylum hydrolysis & - & brown pigment & - \\
Mannitol utilization & $+(\mathrm{w})$ & urease & + \\
Glycerinum utilization & + & Cellulase &
\end{tabular}

+ , positive; - , negative; $+(\mathrm{w})$ weakly positive.

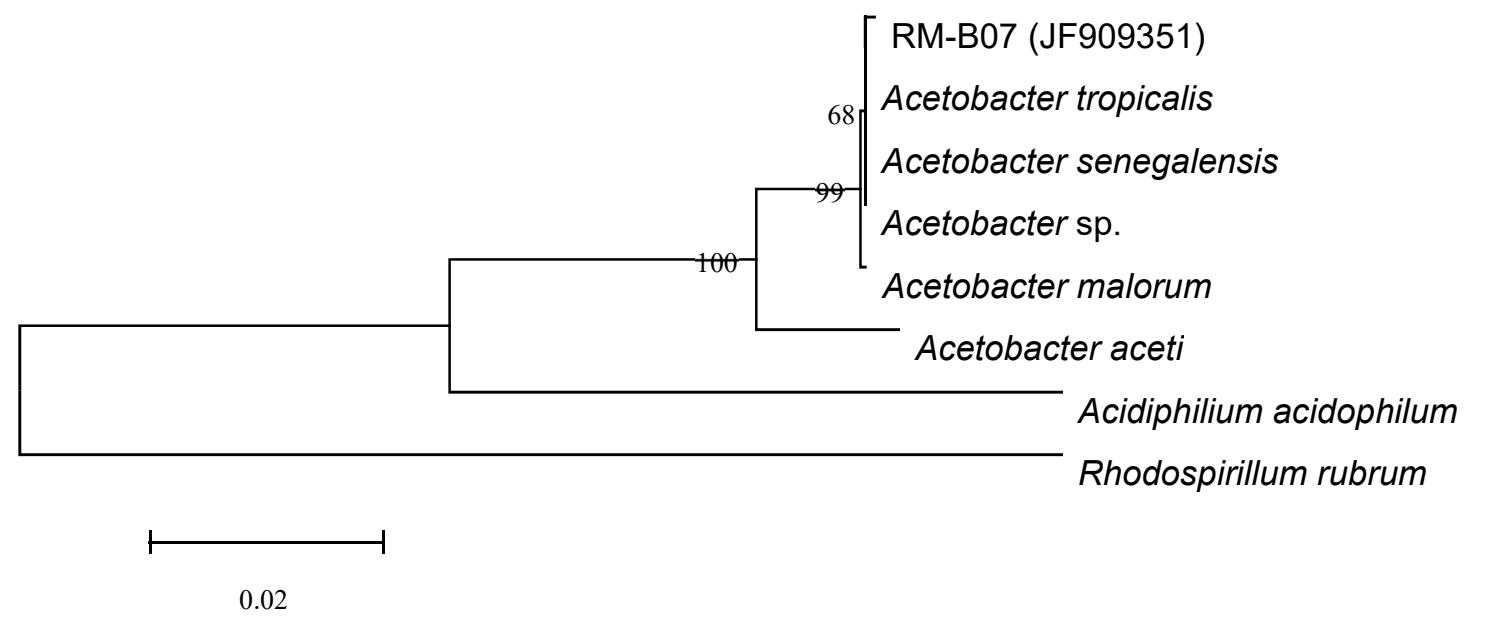

Figure 1. Neighbor-joining phylogenetic tree showing the phylogenetic relationships of the 16S rRNA gene sequences of strain RM-B07 with those related sequences available in GenBank database. Scale 0.02 represents the distance of evolution. Bootstrap replications of 1000 were used.

Bacteria of the genus Acetobacter is widely used for vinegar brewing in industry due to its acidic excretion. A former study reported that Acetobacteraceae was one major ingredient of bacterial communities during the natural restoration of RM impoundment sites through 454 FLX pyrosequencing tests [19]. This conclusion was reconfirmed by this research in another RM impoundment through directly isolating method. Therefore, it can be inferred that Acetobacter plays an important role in reducing the alkalinity of RM in natural environment. 


\subsection{Variation of Baterial Cells and $p H$ Value during Three Different Bioleaching Processes}

The $\mathrm{pH}$ value and growth kinetics of strain Acetobacter sp. in the absence of RM were studied first (Figure 2a). The number of living bacterial cells increased rapidly to the maximum within four days. With the accumulation of toxic secondary metabolite and the depletion of nutrition in the medium, the number of living bacterial cells decreased in the rest time of incubation period. Taking into consideration the $\mathrm{pH}$ value and the number of living cells, after two days of incubation RM particles were added into culture medium under two-step process, as well as six days of incubation the cell-free medium was obtained to perform spent medium process.

Under one-step process at $2 \%$ pulp density (Figure 2a), the proliferation speed of bacterial cells was almost the same as that in the absence of RM, which indicated that Acetobacter sp. was well-adapted to alkaline and saline environment. However, in the last period of leaching process, the number of living cells decreased more rapidly comparing to that in the absence of RM. It was possibly because that Acetobacter sp. needed the limited nutrients in culture medium to keep living rather than to reproduction under extreme environmental stress generated from RM.

In view of bacterial growth and acids output, a two-step process is not superior to a one-step process (Figure $2 b$ ). It was supposed to have a shorter lag phase of bacterial growth in two-step process because the strain was already in exponential phase when RM addition, just like the fungi showed in our previous study [12]. However, an obvious lag phase was observed in the beginning of two-step process at all RM pulp densities in this research.

Under spent medium process (Figure 2c), the $\mathrm{pH}$ value increased slowly throughout the whole process. The previous study demonstrated that long-term ANC of alkaline minerals (e.g., calcite, tricalcium-aluminate, and sodium-aluminum-silicate) in RM was kinetically limited and needed more than 50 days to reach acid-base equilibrium [20].

The $\mathrm{pH}$ value at the end of spent medium process was higher than that in both one- and two-step process at all RM pulp densities, indicating the lowest acids output of strain Acetobacter sp. in spent medium process. The original purpose of employing spent medium process is to avoid the direct contact between leaching materials and microbial cells then protect the cells away from mineral toxicity. However, a directly contact between living cells and RM particles seems to be indispensable for the purpose of increasing acids production of Acetobacter sp. The previous study proved that microorganisms were prone to live on mineral surface to form a microenvironment, which can alleviate the environmental stress and increase the metabolic activity through stress response from cytomembrane stimulation [21]. Another study also reported that physical contact with aluminosilicate mineral is necessary for bacterium Rhodotorula rubra to leach $\mathrm{Al}$ and $\mathrm{Li}$ [22]. Therefore, a moderate contact with RM particles is recommended for designing a practical engineering bioleaching procedure using Acetobacter sp. as the leaching strain.

The survivability of leaching strains in the presence of leaching materials is an important factor determining the bioleaching efficiency. The highest RM pulp density in leaching system could reach up to 10\% for both Aspergillus and Penicillium [3,10-12]. In this study, Acetobacter sp. showed the equivalent tolerability to high RM pulp density as fungi did. Moreover, the lag phase of Acetobacter sp. was shorter than that of Aspergillus or Penicillium by $20-60 \%$ when the strain was contacted with RM, especially at high RM pulp densities.

The biomass weight is also an important parameter determining the processing costs of bioleaching. The biomass weight of Acetobacter sp. was 0.971 and $0.944 \mathrm{mg} / \mathrm{mL}$ respectively in one-and two-step process at $5 \%$ RM pulp density after 10 days bioleaching. Under the similar leaching condition, the biomass of Aspergillus and Penicillium was about 22.0 to $25.0 \mathrm{mg} / \mathrm{mL}$ [3,11], which was over 22.5 times higher than that of Acetobacter sp. This reveals that Acetobacter sp. utilizes less energy for anabolism in leaching system. Thus, the bacterial cell-RM mixture, the byproduct of bioleaching process, is easier to dispose comparing to fungi. 

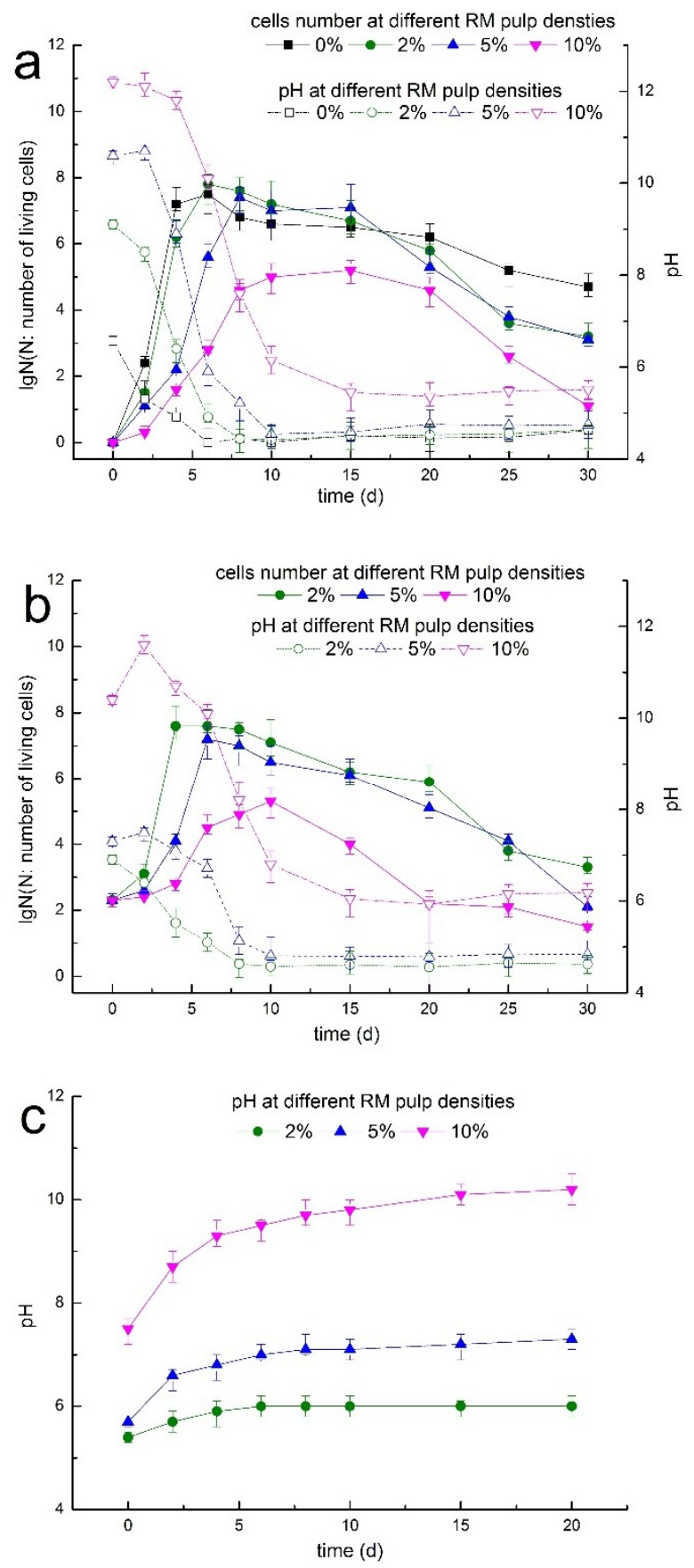

Figure 2. Variation of the number of living cells (solid line) and $\mathrm{pH}$ value (dashed line) under (a) one-step process, (b) two-step process, and (c) spent medium process at $2 \%, 5 \%$, and $10 \%$ RM pulp desities. ( $\mathrm{N}$ on the left $\mathrm{y}$-axis refers to total number of living cells).

\subsection{Bioleaching Perfomance of Metal Elements under Different Bioleaching Processes}

The content ratio of $\mathrm{Al}, \mathrm{Fe}, \mathrm{Ti}$, and $\mathrm{Ca}$ was $3.27 \%, 8.42 \%, 4.14 \%$, and $11.85 \%$ respectively. The content of $\mathrm{U}$, Th was 59 and $201 \mathrm{mg} / \mathrm{kg}$ respectively. The content of $\mathrm{La}, \mathrm{Ce}, \mathrm{Pr}, \mathrm{Nd}, \mathrm{Sm}, \mathrm{Eu}, \mathrm{Gd}$, $\mathrm{Tb}, \mathrm{Dy}, \mathrm{Ho}$, Er, Tm, Yb, and Lu was 416, 842, 95, 341, 64, 110, 56, 184, 48, 25, 28, 14, 28, and $14 \mathrm{mg} / \mathrm{kg}$ respectively. The content ratio of $\mathrm{Al}$ is lower, but $\mathrm{Ca}$ and $\mathrm{Fe}$ is higher comparing to most other $\mathrm{RM}$ in general [23]. This is due to the low-grade bauxite used in the alumina metallurgical refinery. The total content of rare earth elements (REEs) is over $0.26 \%$. Considering that some uranium ores with $0.3 \%$ REEs are recovered economically in USA [24], the REEs in RMs are worth leaching and recovering. The content of Th and $U$ is in the normal range comparing to other RMs [23,25]. 
The leaching ratios of major elements, REEs and radioacitive elements under one-step, two-step and spent medium process are presented respectively in Figure 3. The data of leaching ratios of distilled water and fresh medium without bateria were not present owing to the negligible leaching.
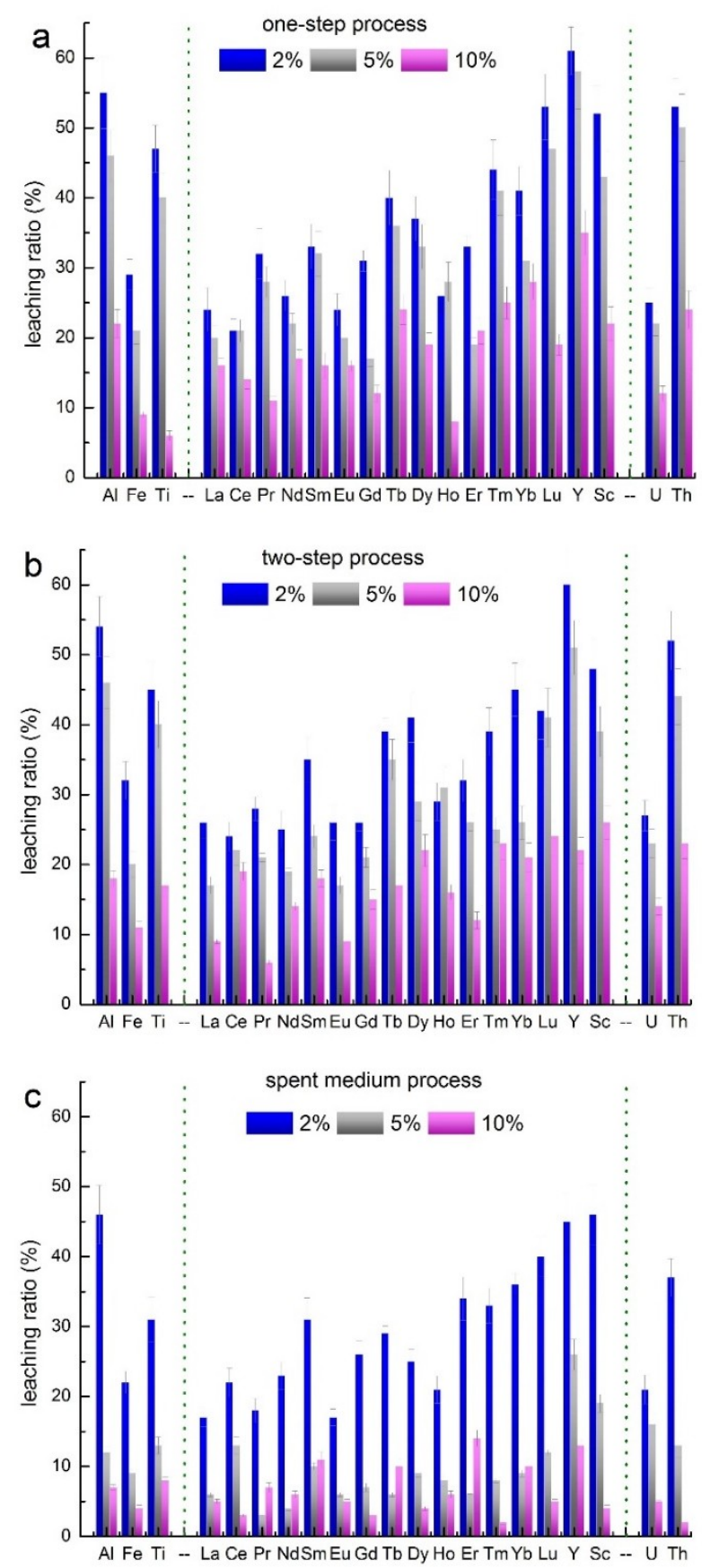

Figure 3. Leaching efficiencies of major elements, REEs and radioactive elements at different RM pulp densities under (a) one-step process, (b) two-step process, and (c) spent medium process.

Strain Acetobacter sp. exhibited a high metal leaching performance of RM. The leaching ratios of $\mathrm{Al}, \mathrm{Lu}, \mathrm{Y}, \mathrm{Sc}$, and $\mathrm{Th}$ was $55 \%, 53 \%, 61 \%, 52 \%$, and $53 \%$ respectively under one-step process at $2 \%$ pulp density. The leaching ratio of $\mathrm{Al}$ was the highest and Fe was the lowest in major elements of RM. This was conducive for recovering $\mathrm{Al}$ since the $\mathrm{Al} / \mathrm{Fe}$ in the leachate was high.

At $2 \%$ of RM pulp density, the leaching performance of one- and two-step process were almost the same, and they were higher than that of spent medium process. Leaching ratios under all the 
bioleaching processes decreased with increase of RM pulp density. However, the decreasing degree of leaching ratios was different. The decreasing degree was the least in one-step process, but the highest in spent medium process. Therefore, the one-step process had the best leaching efficiency at high RM pulp density.

There is always a confusion in bioleaching studies about which process has the best leaching efficiency of metals. Some studies proposed one-step process $[3,11,26]$, some proposed two-step process [27-29], and other recommended spent medium process [12,30-32]. The essential difference among these three bioleaching processes is whether or when the direct physical contact between microbial cells and leaching materials occur. When the physical contact occurs, if the positive effects, e.g., physical destruction of leaching material from cellular growth, increase of microbial metabolite by stress stimulation and lower $\mathrm{pH}$ value in microenvironment upon mineral-cells contact area, are more obvious than the negative effects such as biological toxicity exerted by leaching material, one-step process is preferable. Conversely, spent medium process is recommended. If the positive and negative effect are almost the same, two-step process is preferable. In view of our results as well as the previous studies, it can be reasonably concluded that the leaching strain showing good performance in one-step process is probably the one isolated from the leaching materials or experienced long-time acclimatization with leaching materials. Therefore, it is desirable to isolate functional strains directly from leaching materials for the purpose of improving one-step leaching efficiency.

The economic efficiency is the most important factor restricting the application of heterotrophic microorganism in bioleaching on an industrial scale [8]. The simplest and also cost-optimal engineered way of bioleaching is in-situ heap or dump leaching [7,33]. However, two-step and spent medium processes are difficult to implement in in-situ heap or dump leaching because they need independent bioreactors to culture the microbial cells or acid lixiviant, which results in two different systems operating for the microbial growth and RM leaching respectively. In comparison, a one-step process is easier for up-scaling in in-situ heap or dump leaching. In conclusion, in view of the good leaching efficiency of Acetobacter sp. under direct contact with RM in one-step process, as well as the small production of biomass and lower risk of contaminating environment comparing to fungi, Acetobacter sp. has a great potential in in-situ heap or dump leaching.

\subsection{Radioactivity of RM after Bioleaching}

The application of RM in building materials such as cement and brick, is usually limited by RM radioactivity [34]. Thus, it is pragmatic to evaluate the decrease of RM radioactivity after bioleaching of Acetobacter sp.

If the activity concentration index ( $I$ ) of material exceeds 1.0, it is strictly forbidden to use the RM as materials for cement or brick manufacturing. Activity concentration index can be calculated by the Equation (1) based on the limits for radionuclides in building materials code GB 6566-2010 issued by AQSIQ of China [35], or by Equation (2) based on the radiation protection code issued by European Commission [36] as

$$
\begin{aligned}
& I=C_{\mathrm{Ra}} / 370+C_{\mathrm{Th}} / 260+C_{\mathrm{K}} / 4200 \\
& I=C_{\mathrm{Ra}} / 300+C_{\mathrm{Th}} / 200+C_{\mathrm{K}} / 3000
\end{aligned}
$$

The concentration of radionuclides ${ }^{226} \mathrm{Ra},{ }^{232} \mathrm{Th}$, and ${ }^{40} \mathrm{~K}$ in the raw and bioleached RM residue, as well as the corresponding activity concentration index were showed in Table 2. The activity concentration index of raw RM exceeded the safety limit value of 1.0 based on regulation of both China and Europe. It means that the raw RM collected in our study is forbidden to be used directly as building materials unless value of $I$ decreases to lower than 1.0. After leaching treatment by Acetobacter sp. under one- and two-step process at $2 \%$ pulp density, the value of $I$ was below 1.0 according to the radioactivity standard of China. However, the $I$ value cannot meet the safety limit value under all processes according to the radioactivity standard of Europe. Even so, it can be concluded that 
bioleached RM can be added into construction materials after treatment by Acetobacter sp. with higher ratio compared to raw RM.

Table 2. Radionuclide activity concentration of bioleached RM residue after treatment by one-step, two-step and spent medium processes.

\begin{tabular}{|c|c|c|c|c|c|c|c|c|c|c|}
\hline \multirow{2}{*}{$\begin{array}{c}\text { Radionuclide Activity } \\
\text { Concentration of } \mathrm{RM}^{\mathrm{a}} \\
(\mathrm{Bq} / \mathrm{kg})\end{array}$} & \multicolumn{3}{|c|}{$\begin{array}{c}\text { One-step Process } \\
\text { Pulp Densities }(w / v)\end{array}$} & \multicolumn{3}{|c|}{$\begin{array}{l}\text { Two-step Process } \\
\text { Pulp Densities }(w / v)\end{array}$} & \multicolumn{3}{|c|}{$\begin{array}{l}\text { Spent Medium Process } \\
\text { Pulp Densities }(w / v)\end{array}$} & \multirow{2}{*}{$\begin{array}{l}\text { Raw Red } \\
\text { Mud }\end{array}$} \\
\hline & $2 \%$ & $5 \%$ & $10 \%$ & $2 \%$ & $5 \%$ & $10 \%$ & $2 \%$ & $5 \%$ & $10 \%$ & \\
\hline${ }^{226} \mathrm{Ra}$ & 156.9 & 172.4 & 275.5 & 147.6 & 188.3 & 272.5 & 221.3 & 261.1 & 291.2 & 310.3 \\
\hline${ }^{232} \mathrm{Th}$ & 114.4 & 140.8 & 184.7 & 118.2 & 154.6 & 198 & 140.9 & 175.7 & 203.5 & 219.7 \\
\hline${ }^{40} \mathrm{~K}$ & 245.0 & 296.1 & 313.0 & 273.2 & 320.3 & 354.9 & 321.4 & 366.4 & 382.4 & 423.9 \\
\hline \multicolumn{11}{|c|}{ Activity Concentration Index } \\
\hline$I$ (China) $^{\mathrm{b}}$ & 0.92 & 1.08 & 1.53 & 0.92 & 1.18 & 1.58 & 1.22 & 1.47 & 1.66 & 1.78 \\
\hline$I{\text { (Europe })^{\mathrm{c}}}$ & 1.18 & 1.38 & 1.95 & 1.17 & 1.51 & 2.02 & 1.55 & 1.87 & 2.16 & 2.27 \\
\hline
\end{tabular}

a Values are the means of three experiments: S.D.s $<10 \%$. b I (China): The activity concentration index calculated using Equation (1), i.e., following the GB 6566-2010 code enacted by the Chinese Government. ${ }^{\mathrm{c}} I$ (European): The activity concentration index calculated using Equation (2), i.e., protection 112 code enacted by the European Commission.

\subsection{Organic Acids Secretion of Acetobacter sp.}

The organic acids secreted by leaching strains are deemed as the foremost factor determining the bioleaching efficiency: (i) the protons and the oxygen combining with water and the metal ions will be detached from the protonated surface of leaching material through acidolysis; (ii) the organic acids chelate the metal ions in solution and facilitate the metal dissolution through complexolysis; (iii) the metal toxicity to leaching strains decreases through complexation $[8,33]$. Thus, the organic acids production of Acetobacter sp. were tested (Figure 4).

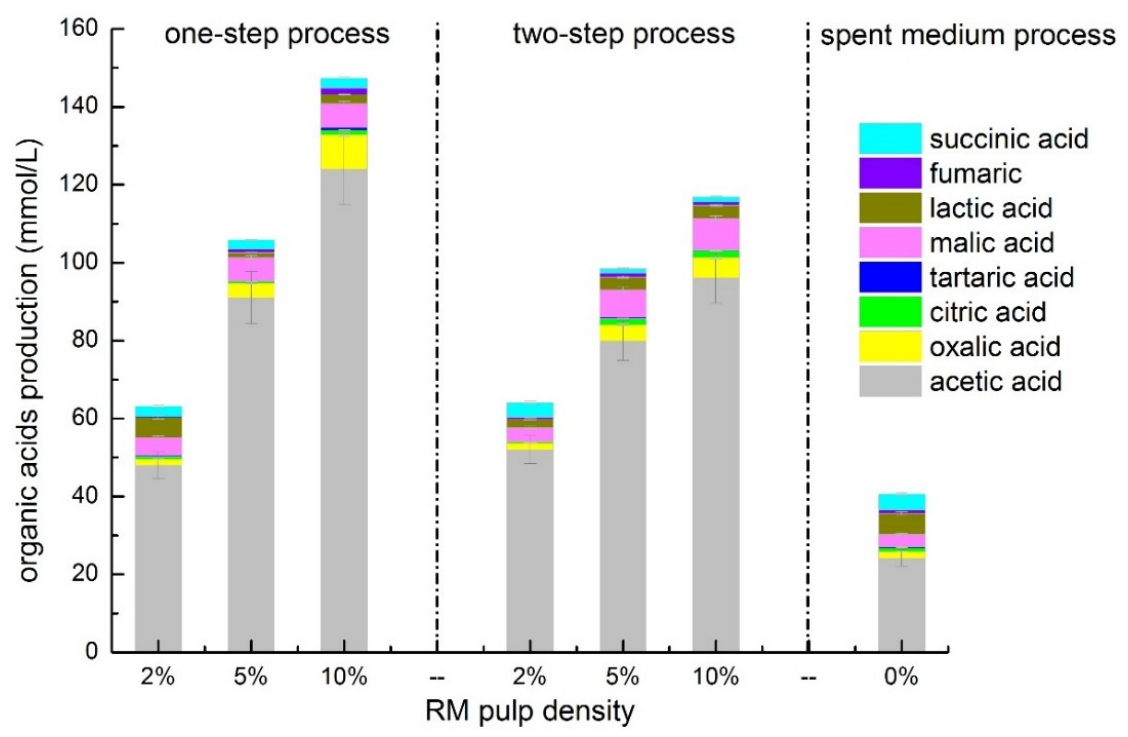

Figure 4. Production of organic acids by Acetobacter sp. under different RM pulp densities and leaching processes.

Under spent medium process without RM, strain Acetobacter sp. mainly secreted acetic, fumaric and succinic acid, as well as slightly secreted oxalic, citric, tartaric, malic and lactic acid. Under oneand two-step processes, the amount of acetic, oxalic and malic acid increased, contrarily the lactic and succinic acid decreased with the increase of RM pulp density from $2 \%$ to $10 \%$.

Moreover, the total amount of acids production increased with the increase of RM pulp density. The microorganisms usually have a strong desire to remold the living environment into their comfort zone, resulting in a dramatic change of external environmental factors such as alkalinity $[9,37]$. Previous study reported that in the presence of $\mathrm{Al}$, the amount of oxalid acid in cells of Pseudomonas 
fluorescens was eight-fold to that in the control cells [38]. There is possibly a similar mechanism for Acetobacter sp. in view of high concentration of $\mathrm{Al}$ in $\mathrm{RM}$. The simultaneous increase of acetic and oxalic acids in one- and two-step process indicated that the activity of oxaloacetase (can hydrolyze oxaloacetate to oxalate and acetate) in the cells of Acetobacter sp. was enhanced with an increase of RM concentration [39]. In a word, it is conducive to improve the bioleaching efficiency of strain Acetobacter sp. at high RM pulp density.

\subsection{Change of Mineral Composition during Bioleaching of RM by Acetobacter sp.}

The X-ray diffraction (XRD) analysis of raw as well as bioleached RM (after one-step process at $2 \%$ pulp density) was deployed (Figure 5). The XRD peaks indicate that the main mineral components of raw RM is boehmite $(\mathrm{AlOOH})$, calcite $\left(\mathrm{CaCO}_{3}\right)$, gibbsite $\left(\mathrm{Al}(\mathrm{OH})_{3}\right)$, goethite $(\mathrm{FeOOH})$, hematite $\left(\mathrm{Fe}_{2} \mathrm{O}_{3}\right)$, perovskite $\left(\mathrm{CaTiO}_{3}\right)$, and sodalite $\left(\mathrm{Na}_{4} \mathrm{Al}_{3} \mathrm{Si}_{3} \mathrm{O}_{12} \mathrm{Cl}\right)$, which coincides with the major elemental composition of RM analyzed by total digestion.

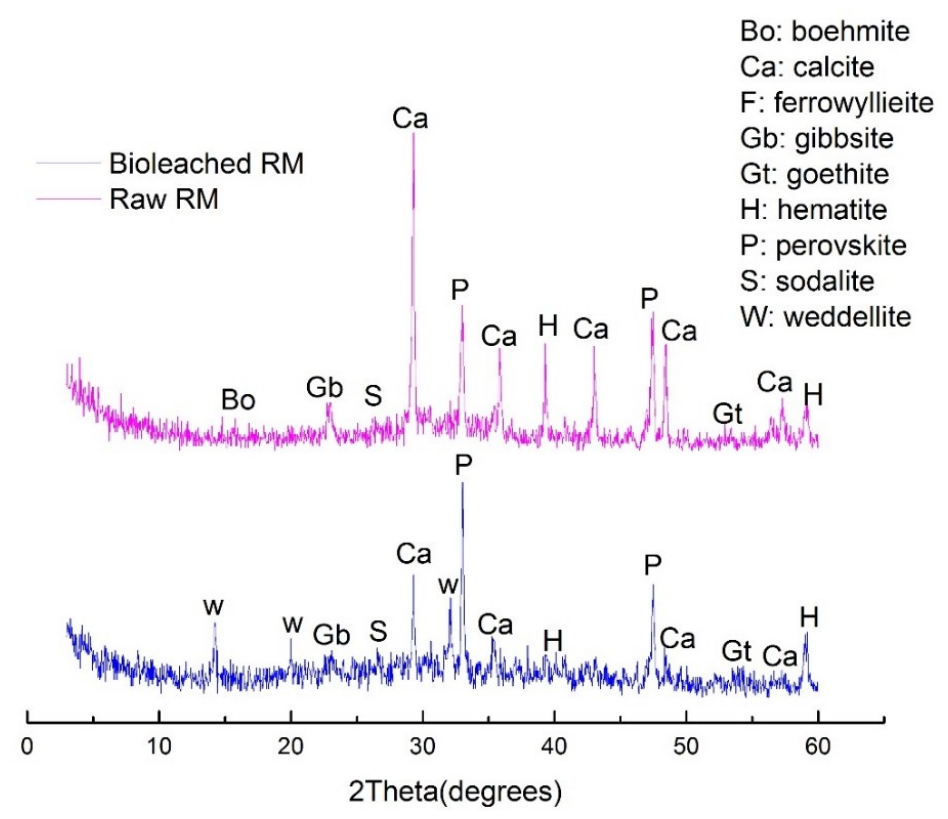

Figure 5. XRD analysis of raw and bioleached RM.

The content of calcite, hematite and gibbsite decreased in bioleached RM, indicating these minerals were corroded easily by Acetobacter sp. This is in accordance with the results that $\mathrm{Ca}, \mathrm{Fe}$, and $\mathrm{Al}$ were leached efficiently from RM (Section 3.3). However, perovskite was difficult to be corroded by Acetobacter sp. since the relative content in bioleached RM increased. It is noteworthy that a new mineral-weddellite appeared in RM after bioleaching. This is probably due to the precipitation reaction between $\mathrm{Ca}^{2+}$ dissolved from $\mathrm{RM}$ and oxalic acid generated by bacterial metabolism.

\subsection{Micromorphology of RM Particles and Acetobacter sp.}

For probing the interaction between Acetobacter sp. and RM particles, the micromorphology was observed by scanning electron microscope (SEM) (Figure 6). The raw RM comprised various sizes of particles normally ranging from 0.05 to over $50 \mu \mathrm{m}$ with rough surface and poor crystalline structure. The particles bonded together to form large fluffy aggregates (Figure 6a). The cell size of Acetobacter sp. ranged from 1.0 to $4.0 \mu \mathrm{m}$, and a depression appeared in the middle of the oval cell surface (Figure 6b).

Under bioleaching process, more smaller RM particles appeared due to the acidifying erosion by bacterial metabolites and respiration (Figure 6c,d). The cells of Acetobacter sp., adhered by small RM particles aggregated together and then adhered to large RM particles. The formation of cellular aggregates is probably a strategy for bacteria to withstand the multiple stress from RM toxicity. 
A mass of cells embedded into the crack and lacuna of RM formed by biochemical erosion of bacterial metabolism and biophysical destruction of cellular growth. This can enlarge the contact area between cells and RM minerals and provide more reactive sites. The previous study demonstrated that the cellular dissolution by fungus can account for $40-50 \%$ of the overall bio-weathering of minerals [40]. According to our SEM analysis, bacterial cells of Acetobacter sp. also play an important role in weathering and dissolution of RM particles.

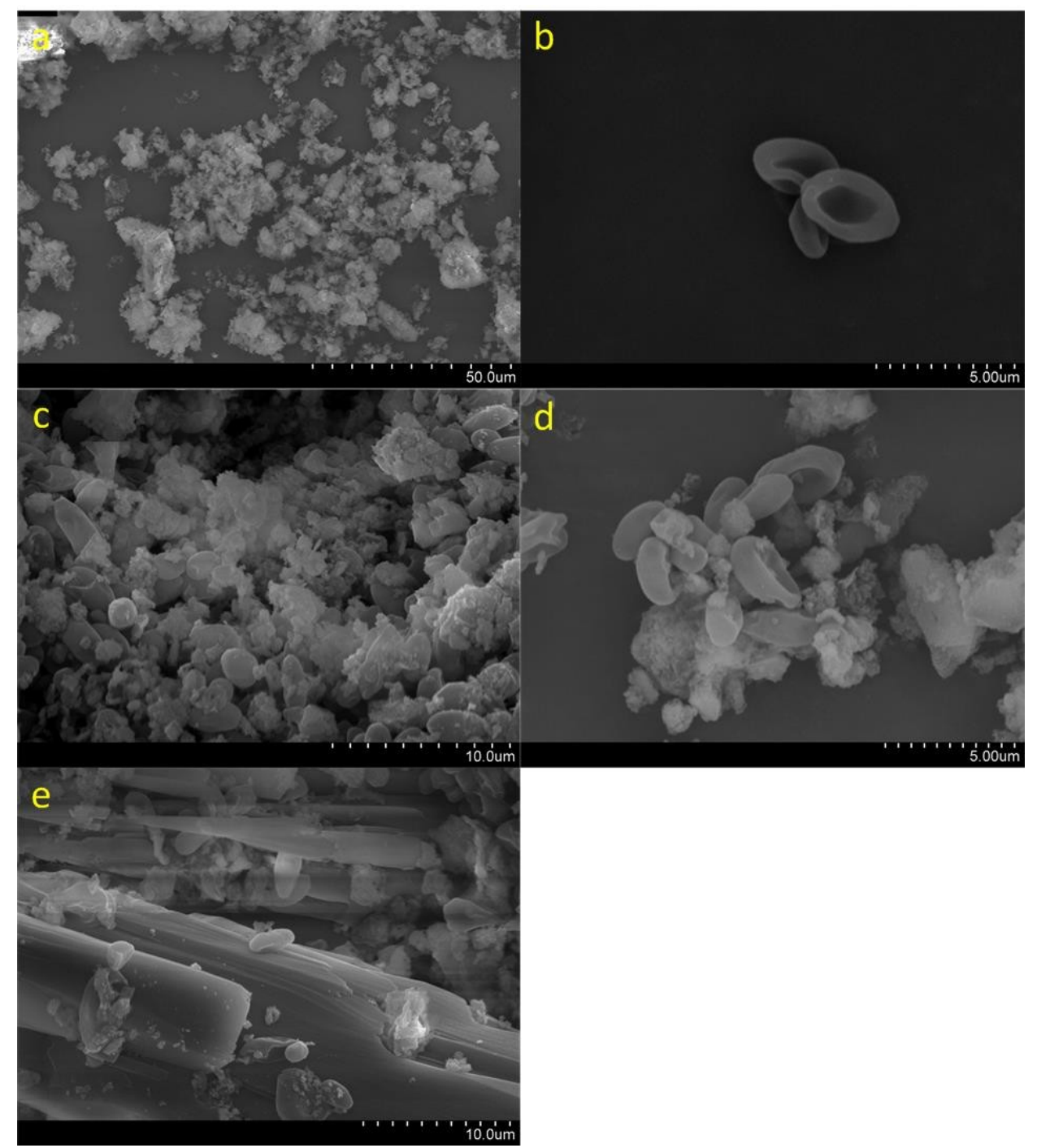

Figure 6. SEM images of (a) raw RM, (b) Acetobacter sp., (c) cells of Acetobacter sp. adhering to $\mathrm{RM}$ under one-step process, (d) bacterial cells and RM aggregates, and (e) recrystallization during bacterial bioleaching.

It was intriguing that a new crystal appeared in the bioleached RM through recrystallization (Figure 6e). It was most likely the weddellite based on the analysis of energy dispersive spectrum (EDS). However, the bio-recrystallisation was not observed during the RM bioleaching by using $A$. niger and P. tricolor in our previous studies [3,41]. Maybe this is a unique feature of Acetobacter sp. for RM leaching.

\section{Conclusions}

This work indicated that major elements, REEs and radioactive elements in RM were effectively leached by Acetobater sp. The RM can be directly used as construction materials after bioleaching at low pulp density based on radioactivity regulations in China. The mineral composition of RM 
changed obviously, and a new crystal of weddellite was observed after bioleaching by Acetobater sp. It was suitable for Acetobater sp. to bioleaching RM at high pulp densities, because the total amount of organic acids excreted by Acetobater sp. increased with an increase of RM concentration. In view of the desirable leaching efficiency under direct contact with RM, as well as shorter lag phase, smaller biomass and lower risk of contaminating environment comparing to fungi, strain Acetobacter sp. have a potential in in-situ heap or dump bioleaching of RM.

Author Contributions: Experiments, Y.Q., H.L. and B.S.; writing-original draft preparation, Y.Q.; writing-review and editing, H.L., X.W., W.T., M.Y. and Y.Z.

Funding: This research was funded by Natural Science Foundation of China $(41701306,51804155)$, Breakthrough of Science and Technology of Henan Province (172102310247, 182102311035), Key Scientific Research Projects of Univiersity in Henan (16A610010, 17B610007, 15A180049).

Conflicts of Interest: The authors declare no conflict of interest. The funders had no role in the design of the study; in the collection, analyses, or interpretation of data; in the writing of the manuscript, or in the decision to publish the results.

\section{References}

1. Power, G.; Gräfe, M.; Klauber, C. Bauxite residue issues: I. Current management, disposal and storage practices. Hydrometallurgy 2011, 108, 33-45. [CrossRef]

2. Xue, S.; Zhu, F.; Kong, X.; Wu, C.; Huang, L.; Huang, N.; Hartley, W. A review of the characterization and revegetation of bauxite residues (Red mud). Environ. Sci. Pollut. Res. Int. 2016, 23, 1120-1132. [CrossRef] [PubMed]

3. Qu, Y.; Lian, B. Bioleaching of rare earth and radioactive elements from red mud using Penicillium tricolor RM-10. Bioresour. Technol. 2013, 136, 16-23. [CrossRef] [PubMed]

4. Klauber, C.; Gräfe, M.; Power, G. Bauxite residue issues: II. options for residue utilization. Hydrometallurgy 2011, 108, 11-32. [CrossRef]

5. Borra, C.R.; Blanpain, B.; Pontikes, Y.; Binnemans, K.; Van Gerven, T. Recovery of Rare Earths and Other Valuable Metals from Bauxite Residue (Red Mud): A Review. J. Sustain. Metall. 2016, 2, 365-386. [CrossRef]

6. Brandl, H.; Barmettler, F.; Castelberg, C.; Fabbri, C. Microbial mobilization of rare earth elements (REE) from mineral solids-A mini review. AIMS Microbiol. 2016, 2, 190-204. [CrossRef]

7. Brierley, C.L.; Brierley, J.A. Progress in bioleaching: Part B: Applications of microbial processes by the minerals industries. Appl. Microbiol. Biotechnol. 2013, 97, 7543-7552. [CrossRef] [PubMed]

8. Burgstaller, W.; Schinner, F. Leaching of metals with fungi. J. Biotechnol. 1993, 27, 91-116. [CrossRef]

9. Santini, T.C.; Kerr, J.L.; Warren, L.A. Microbially-driven strategies for bioremediation of bauxite residue. J. Hazard. Mater. 2015, 293, 131-157. [CrossRef]

10. Urik, M.; Bujdos, M.; Milova-Ziakova, B.; Mikusova, P.; Slovak, M.; Matus, P. Aluminium leaching from red mud by filamentous fungi. J. Inorg. Biochem. 2015, 152, 154-169. [CrossRef] [PubMed]

11. Vakilchap, F.; Mousavi, S.M.; Shojaosadati, S.A. Role of Aspergillus niger in recovery enhancement of valuable metals from produced red mud in Bayer process. Bioresour. Technol. 2016, 218, 991-998. [CrossRef] [PubMed]

12. Qu, Y.; Lian, B.; Mo, B.; Liu, C. Bioleaching of heavy metals from red mud using Aspergillus niger. Hydrometallurgy 2013, 136, 71-77. [CrossRef]

13. Krishna, P.; Babu, A.G.; Reddy, M.S. Bacterial diversity of extremely alkaline bauxite residue site of alumina industrial plant using culturable bacteria and residue 16S rRNA gene clones. Extremophiles 2014, 18, 665-676. [CrossRef] [PubMed]

14. Buchanan, R.E. Bergey's Manual of Determination Bacteriology, 8th ed.; Science Press: Beijing, China, 1984.

15. Li, H.; Liu, D.; Lian, B.; Sheng, Y.; Dong, H. Microbial Diversity and Community Structure on Corroding Concretes. Geomicrobiol. J. 2012, 29, 450-458. [CrossRef]

16. Shabani, M.A.; Irannajad, M.; Azadmehr, A.R.; Meshkini, M. Bioleaching of copper oxide ore by Pseudomonas aeruginosa. Int. J. Min. Met. Mater. 2013, 20, 1130-1133. [CrossRef]

17. Banning, N.C.; Phillips, I.R.; Jones, D.L.; Murphy, D.V. Development of Microbial Diversity and Functional Potential in Bauxite Residue Sand under Rehabilitation. Restor. Ecol. 2011, 19, 78-87. [CrossRef] 
18. Krishna, P.; Arora, A.; Reddy, M.S. An alkaliphilic and xylanolytic strain of actinomycetes Kocuria sp. RM1 isolated from extremely alkaline bauxite residue sites. World J. Microb. Biot. 2008, 24, 3079-3085. [CrossRef]

19. Schmalenberger, A.; O'Sullivan, O.; Gahan, J.; Cotter, P.D.; Courtney, R. Bacterial communities established in bauxite residues with different restoration histories. Environ. Sci. Technol. 2013, 47, 7110-7119. [CrossRef]

20. Khaitan, S.; Dzombak, D.A.; Lowry, G.V. Chemistry of the acid neutralization capacity of bauxite residue. Environ. Eng. Sci. 2009, 26, 873-881. [CrossRef]

21. Zobell, C.E. The effect of solid surfaces upon bacterial activity. J. Bacteriol. 1943, 46, 39-56.

22. Rezza, I.; Salinas, E.; Elorza, M.; Tosetti, M.; Donati, E. Mechanisms involved in bioleaching of an aluminosilicate by heterotrophic microorganisms. Process Biochem. 2001, 36, 495-500. [CrossRef]

23. Gräfe, M.; Power, G.; Klauber, C. Bauxite residue issues: III. Alkalinity and associated chemistry. Hydrometallurgy 2011, 108, 60-79. [CrossRef]

24. Smirnov, D.I.; Molchanova, T.V. The investigation of sulphuric acid sorption recovery of scandium and uranium from the red mud of alumina production. Hydrometallurgy 1997, 45, 249-259. [CrossRef]

25. Xue, S.; Kong, X.; Zhu, F.; Hartley, W.; Li, X.; Li, Y. Proposal for management and alkalinity transformation of bauxite residue in China. Environ. Sci. Pollut. Res. Int. 2016, 23, 12822-12834. [CrossRef] [PubMed]

26. Amiri, F.; Yaghmaei, S.; Mousavi, S.M.; Sheibani, S. Recovery of metals from spent refinery hydrocracking catalyst using adapted Aspergillus niger. Hydrometallurgy 2011, 109, 65-71. [CrossRef]

27. Amiri, F.; Yaghmaei, S.; Mousavi, S.M. Bioleaching of tungsten-rich spent hydrocracking catalyst using Penicillium simplicissimum. Bioresour. Technol. 2011, 102, 1567-1573. [CrossRef] [PubMed]

28. Yang, J.; Wang, Q.; Wang, Q.; Wu, T. Comparisons of one-Step and two-Step bioleaching for heavy metals removed from municipal solid waste incineration fly ash. Environ. Eng. Sci. 2008, 25, 783-789. [CrossRef]

29. Aung, K.M.; Ting, Y.P. Bioleaching of spent fluid catalytic cracking catalyst using Aspergillus niger. J. Biotechnol. 2005, 116, 159-170. [CrossRef] [PubMed]

30. Vachon, P.; Tyagl, R.D.; Auclair, J.C.; Wilkinson, K.J. Chemical and biogical leaching of Al from red mud. Environ. Sci. Technol. 1994, 28, 26-30. [CrossRef] [PubMed]

31. Horeh, N.B.; Mousavi, S.M.; Shojaosadati, S.A. Bioleaching of valuable metals from spent lithium-ion mobile phone batteries using Aspergillus niger. J. Power Sources 2016, 320, 257-266. [CrossRef]

32. Rasoulnia, P.; Mousavi, S.M.; Rastegar, S.O.; Azargoshasb, H. Fungal leaching of valuable metals from a power plant residual ash using Penicillium simplicissimum: Evaluation of thermal pretreatment and different bioleaching methods. Waste Manag. 2016, 52, 309-317. [CrossRef] [PubMed]

33. Bosecker, K. bioleaching metal solubilization by microorganisms. FEMS Microbiol. Rev. 1997, 20, 591-604. [CrossRef]

34. Somlai, J.; Jobbagy, V.; Kovacs, J.; Tarjan, S.; Kovacs, T. Radiological aspects of the usability of red mud as building material additive. J. Hazard. Mater. 2008, 150, 541-555. [CrossRef] [PubMed]

35. GB6566-2001, Limit of Radionuclides in Building Materials; State Administration for Quality Supervision and Inspection and Quarantine (AQSIQ): Beijing, China, 2011.

36. Radiation protection 112, Radiological Protection Principles Concerning the Natural Radioactivity of Building Materials; European Commission: Brussel, Belgium, 1999.

37. Harris, J. Soil microbial communities and restoration ecology: Facilitators or followers? Science 2009, 325, 573-574. [CrossRef] [PubMed]

38. Hamel, R.; Levasseur, R.; Appanna, V.D. Oxalic acid production and aluminum tolerance in Pseudomonas fluorescens. J. Inorg. Biochem. 1999, 76, 99-104. [CrossRef]

39. Dutton, M.V.; Evans, C.S. Oxalate production by fungi: Its role in pathogenicity and ecology in the soil environment. Can. J. Microbiol. 1996, 42, 881-895. [CrossRef]

40. Li, Z.; Liu, L.; Chen, J.; Teng, H.H. Cellular dissolution at hypha- and spore-mineral interfaces revealing unrecognized mechanisms and scales of fungal weathering. Geology 2016, 44, 319-322. [CrossRef]

41. Qu, Y.; Li, H.; Tian, W.; Wang, X.; Wang, X.; Jia, X.; Shi, B.; Song, G.; Tang, Y. Leaching of valuable metals from red mud via batch and continuous processes by using fungi. Miner. Eng. 2015, 81, 1-4. [CrossRef]

(C) 2019 by the authors. Licensee MDPI, Basel, Switzerland. This article is an open access article distributed under the terms and conditions of the Creative Commons Attribution (CC BY) license (http:// creativecommons.org/licenses/by/4.0/). 